\title{
Proceeding
}

Supplementary Issue: Summer Conferences of Sports Science. Costa Blanca Sports Science Events, 20-21 September 2019.

Alicante, Spain.

\section{The importance of sports education in the primary school: An experimental pedagogical project}

\author{
DAVIDE DI PALMA $\triangle$, SALVATORE IOVINO, ANTONIO ASCIONE \\ Parthenope University, Naples, Italy
}

\begin{abstract}
The educational role of sport in the various socio-relational contexts is now an internationally consolidated reality; however, in the Italian school context, especially at primary level, sports activity still does not have the possibility to express all its pedagogical potential. In this regard, this research work aims at proving the ability to develop indispensable skills for a complete growth of children, through a pedagogical experimental project in the field of motor-sports education at school level. This research work involves a heterogeneous class of a primary school, and was carried out within a limited period of time during school hours. Its outcomes confirm the basic hypothesis, and are proposed as a solid basis for future studies in experimental pedagogy applied to the field of motor and sports sciences. Keywords: Sports education; School context; Experimental pedagogy; Motor and sports sciences.
\end{abstract}

\section{Cite this article as:}

Di Palma, D., lovino, S. \& Ascione, A. (2019). The importance of sports education in the primary school: An experimental pedagogical project. Journal of Human Sport and Exercise, 14(5proc), S1908-S1924. doi:https://doi.org/10.14198//hse.2019.14.Proc5.10

Corresponding author. Parthenope University, Naples, Italy.

E-mail: davide.dipalma@uniparthenope.it

Supplementary Issue: Summer Conferences of Sports Science. Costa Blanca Sports Science Events, 20-21 September 2019. Alicante, Spain.

JOURNAL OF HUMAN SPORT \& EXERCISE ISSN 1988-5202

(c) Faculty of Education. University of Alicante

doi:10.14198/jhse.2019.14.Proc5.10 


\section{INTRODUCTION}

Primary school plays a very important role in stimulating the learning of basic values and skills for the current and future training of young learners. In this context, it is essential to find experimental solutions capable of making the educational and didactic strategy more effective and efficient (Ascione, Di Palma \& Napolitano, 2018; Bailey, 2005; Di Palma, Rosa \& Ascione, 2019). To this purpose, this research work analyses the effects of an experimental pedagogical program in the field of motor and sports sciences, which is mainly based on the playful aspect, and makes use of the fairy tales tool to increase children's educational level, both in didactic and social terms.

Everything starts from the story of a fairy tale, a magical place of fantasy, where one meets characters, animals and unknown places. The child is captured by the narration, and hence the animated path begins expression, play, movement and relationship with the group are its main ingredients. Through storytelling and motor and sports activities carried out in specifically designed playful paths, we will try to create "magical" opportunities for the acquisition of basic motor schemes. The playful world of fairy tales is that experimental pedagogical place where all living beings are on the same level, and through which new mutual relationships arise with particular rules, set out by the feeling and ingenuity of children.

The teacher's attitude was participatory, leading the children to discover the rules for playing together, listening, not getting hurt and putting things back in their place. Children was encouraged to act, reflect on their own actions and experience themselves in relation to others; moreover, they became aware of their own body, and movement was their first learning factor: searching for something, discovering, playing, jumping and running to school was sources of well-being and psycho-physical balance. Body actions will make experience pleasant emotions and sensations of relaxation and tension; they will allow experiencing the potential of one's own physicality, by developing, at the same time, the awareness of the risks of uncontrolled movements (Ascione, Di Palma \& Rosa, 2018; Di Palma, Ascione \& Napolitano, 2018; Napolitano, Ascione \& Di Palma, 2018). Children played with their own bodies, communicate, express themselves through mimics, put themselves to the test, and even in these ways, they was able to perceive the completeness of their own self, consolidating autonomy and emotional confidence (Rosa, Ascione \& Di Palma, 2019; Whipp et al, 2011).

\section{THE STRUCTURE OF THE PEDAGOGICAL EXPERIMENTAL PROJECT}

\section{Recipients}

The project we proposed is aimed at children aged five years and over, attending kindergarten.

The class was made up of eighteen children, ten of whom were girls and eight were boys. In addition, a child suffered from total lack of sight in both eyes and his binocular perimetric residual was below $3 \%$. For this reason, the student was undergoing a therapeutic path at a clinic, which saw him engaged once a month in school hours; during the planning of the activities, this aspect was taken into account. The blind student, who would later be identified as $1 \mathrm{M}$, would build an image through the touch and the hearing, and therefore would acquire images of the analytical and syncretic world by using a tactile-hearing memory. There was no synthesis phase automatically provided by sight, so he had difficulties in abstracting and generalizing. The direct experience for $1 \mathrm{M}$ is always basic, since is allows developing the reference images of what must be learnt. The teacher was aware of the difficulties resulting from the sight problem; this helped him better understand the student's limits and potentialities, thus avoiding incurring attitudes of overprotection or excessive expectations. In the same way, the student's family could have developed an excessive sense of protection, so it was adequately informed about the organizational and operational modalities of the project. 
In the practical execution of the activities, the class teacher was helped by the supporting teacher, who guided $1 \mathrm{M}$ by promoting the knowledge for exploration.

Taking into account $1 \mathrm{M}$ 's medical-oculistic certification, its Functional Diagnosis and IEP, the project we proposed paid particular attention to the creation of a motor learning path that could have allowed everyone expressing his own potential, taking care to respect the specific disability of the child and build a positive and meaningful interpersonal relationship, in which any type of learning possibility would have become concrete.

\section{Objectives}

- $\quad$ Coordinating and using different motor schemes combined with each other, by exploring their possibilities of motor and gestural language.

- $\quad$ Recognizing executive rhythms and temporal sequences of motor actions, knowing how to organize one's own movement in space in relation to oneself, objects and others.

- $\quad$ Participating actively in the various forms of game, including competitions, by teaming up with others.

- $\quad$ Respecting the rules of the games proposed.

\section{Goals for competence development}

- Recognizing the signals and rhythms of one's own body.

- $\quad$ Enjoying movement and experiencing postural and motor patterns, applying them in individual and group games, even by using small tools and being able to adapt them to environmental situations, both at school and outdoors.

- $\quad$ Controlling gesture performance, assessing risk, interacting with others in games of movement, music and expressive communication.

- Developing awareness of one's own body, motor coordination, and psycho-physical balance.

\section{Place}

The "Fiabe in movimento" (Moving Fairy Tales) project took place at a kindergarten.

\section{Spaces}

The proposed activities took place partly in the gymnasium of the school, and partly in the classroom of the section under analysis. In addition, the garden outside the school was used too.

\section{Timing}

The project had a total duration of twenty hours, divided into ten weeks, with meetings of two hours each.

\section{Tools}

The following fairy-tale books were used in the classroom:

- $\quad$ Peter Pan

- $\quad$ The Adventures of Pinocchio

- $\quad$ Snow-White and the Seven Dwarfs.

In the gym students used coloured circles, cones, marker cones, rods, balls, small balls, mats, benches, sponges, baskets, tambourines, stereos, timers, laces, bands, balls of wool, player pianos, game parachutes, bowls with different materials (sand, pebbles, water, leaves, wadding), cellophane with bubbles. 


\section{EXPERIMENTAL SCHOOL EXPERIENCE ACTIVITIES PROGRAM}

The project we proposed aimed at considering both the sports and the educational-pedagogical aspects, making fairy-tale embrace the world of motor activity (Männistö et al, 2006; McKenzie et al, 2010). We chose to make our lesson last for two hours; the first half hour was dedicated to reading the fairy-tale chosen in the classroom, then the children moved to the school gym to carry out motor activities. Three weeks of lessons were dedicated to each fairy-tale, for a total of six hours; in the last week a final debriefing lesson was proposed, in which the children had the opportunity to repeat the games they liked most.

\section{Week 1}

The lesson started with the reading of Peter Pan's fairy-tale in the classroom, which was then reproduced in several "stages" through motor games carried out in the gym. The fairy tale of this first lesson tells of three children, named Wendy, Michele and Gianni; after meeting Peter Pan, they were convinced to follow him to the Never-never land, and by holding their hands without ever leaving each other, they flew from the window of their house above the rooftops of London. On the island, the boys lived fantastic adventures and came across the Indians' hideout, which hid a path full of pitfalls and traps in which it was very easy to fall into! Towards the Never-never land: By resuming the story, the teacher showed the motor path that the students had to carry out, and divided them into groups of three, like the protagonists. As he said "GO" the music started, and each group of three children, by holding each other's hands, performed the path: a slalom between six cones, followed by the overcoming of three raised obstacles laying on two cones placed at the sides, two jumps within two large circles arranged on the ground, then a run on a mat and went go back in the order they had been arranged in. The path was performed in pairs, one of the components was blindfolded, and the other played the leading role. At the end of the path, the components of the couples reversed their roles, and the teacher, with the same materials, set up a new sequence to play. This activity was designed to encourage the involvement of $1 \mathrm{M}$, bearer of difficulties mentioned above, and to make the child feel like the others, without any discrimination.

At the Indian village: Considering the moment of the story in which the children were in the hideout of the Indians, the teacher exhorted the students to stay alert; in Indian row, they had to perform individually another motor path within a certain time limit ( 3 minutes on the timer) so as not to be discovered by the Indians. This involved jumping together in six zigzag arranged circles on the ground, walking balanced along the yellow field line, entering a long tunnel, running, rolling on a mat and finishing the path by walking balanced on a bench. Also, $1 \mathrm{M}$ was involved; in fact, his task was to play the tambourine, once to start the game and twice to finish it.

\section{Week 2}

The teacher kept reading the story until Peter Pan met Captain Hook. The three brothers in the story, at a certain point, found themselves in the hideout of the lost children, where they made friends and played together.

The Lost Children's Hideout: In relation to it, in one place of the gym, the teacher proposed a group game to the students, involving the use of the ball: he let the children sit on the ground and gave a ball to a child, who had to pass to the one sitting next to him/her, while calling him/her by name, to the sound of the music. When the music stopped, the person who took the ball got a forfeit in the middle of the circle. The aim of the game was to quickly pass the ball to the one lying next to each child, before the music got stopped. 
This activity required cooperative and participative spirit, since the mates would have probably incited each other. This gave $1 \mathrm{M}$ the chance to play too.

This was the most awaited moment: the meeting between Peter Pan and the evil Captain Hook!

The Fight: The teacher organizes the fight through a game that took place in the gym, previously divided into two parts. Two teams were set up: one led by Peter Pan and the other by Captain Hook. The game involved throwing as many sponges as possible into the opponent's field, in a certain time limit, trying to clear one's own field. The sponges, in fact, symbolized the bombs that Captain Hook and Peter Pan were throwing at each other. In this battle, 1M gave indications on how to throw the sponges: "Throw the sponges forward", "Throw the sponges backwards", "Throw the sponges with your feet" etc. At the final whistle, the sponges in each field were counted, and the team with fewer sponges won.

The fight between Peter Pan and Captain Hook was not over yet...

The final fight: The children faced a duel, in which they were divided into two teams again. One group represented Peter Pan and the other Captain Hook. A rope placed on the ground delimited Captain Hook's shelter, which didn't have to be invaded by Peter Pan and his team in no way. When the latter felt asleep, Captain Hook's team was free to move in the gym. When Peter Pan woke up and shouted, he started chasing the opposing team that then ran and took shelter. The captured Captain Hook group's children became Peter Pan's companions, and all together hunted down Captain Hook and his friends. The game was considered over when the whole Captain Hook's team got captured.

\section{Week 3}

The teacher completed the reading of the fairy tale of Peter Pan. The three brothers begun to miss the house and their parents, so Peter Pan urged all the children to recover their stuff, and with the pirate vessel conquered, made them fly to London.

As already mentioned, $1 \mathrm{M}$ was absent this week.

Back home: The teacher organized a relay in which the students had to retrieve all the objects to carry in the vessel from a box, i.e. the balls in a basket. Each person had to take the ball into the basket and score a basket behind a yellow line, after performing a final slalom course on six cones by carrying the ball in his hand. After scoring at least ten baskets, the game could be considered over.

At this point the children had to compete with each other to get a place to go home!

Speed race: The children were in a circle by holding each other's hands, and only one child remained outside. The latter started running around his companions, suddenly touching the back of the child he wanted to challenge. The two players started running around the circle in opposite directions, and the child who managed to complete the circle and get to the place first had the win. The student left out had to repeat the just described game sequence, in order to earn his place to go back home.

Let's run to the lifeboats! To the sound of music, the children were free to walk by taking up all the space of the gym. At a certain point, the teacher stopped the music and ordered his students to assemble lifeboats, i.e. groups of two, three or four children, and a point was assigned to each member of the group who had correctly set one up more quickly. 
With these activities, the three weeks dedicated to Peter Pan's fairy tale could be considered over. To maintain and consolidate the skills that had been promoted so far, the children could continue to experience themselves through game and body movement, passing from free games to rules-based games, from materials-based games to those symbolic, through the fairy tale The Adventures of Pinocchio.

\section{Week 4}

To give continuity and confidence to the students, the way the fairy tale The Adventures of Pinocchio was approached followed the same approach as the previous one. In fact, the lesson began with the reading of the fairy tale in the classroom of the section involved, which was reproduced in several "stages" through motor games in the gym.

The first lesson involved reading the part of the story up to when Pinocchio $m$ with the cat and the fox. By resuming the moment in which the protagonist was built by working the various parts of his body with wood, the game of magnets then began.

The magnets: The children run freely in the gym; when the teacher would say "Magnet... in your hands!" each child had to stick to another child, putting the part of their body mentioned close to each other. At that point, it was declared that the magnet was broken, and the children detached themselves, starting to move freely in space. The teacher called for the magnet by referring to another part of the body. It was also be possible to call for magnets with different parts of the body at the same time, in order to work on mirror coordination, balance and lateralization. For this game, 1M was assisted by the supporting teacher, who guided him throughout the entire activity.

As the fairy tale says, the cat and the fox are two characters that would always travel together, and steal coins from Pinocchio.

The cat and the fox: The game involved a path in which the players were divided into pairs; each component of the pair tied one of his legs to that of his partner, so as to perform a three-legged race. During this race they had to face the following tests: the first one consisted in a slalom between cones; then it followed the jump beyond the rope (if they were wrong, they had to start again from the beginning); finally, the combined shot on goal that involved throwing the ball in a goal by using the foot in common of the two players. The game was considered over when each pair had finished the path.

To carry out the previous activities we did not established a time limit, as we believe that it was essential to respect the children's rhythms and times, valuing their individuality and their needs. In this way, an environment characterized by serenity and not competitiveness would have been favoured. For these reasons, particular attention was paid to the inclusion of $1 \mathrm{M}$, who carried out the planned paths just like his mates.

The reading of the first day dedicated to the fairy tale of Pinocchio ended with the protagonist who, saddened by the fact that the cat and the fox had stolen his coins, starts crying. Suddenly the fairy appeared and comforted him. She asked Pinocchio to tell her what had happened, but he, as a good liar, told her that he had lost them, while he had actually given them to the cat and the fox. After these lies Pinocchio's nose began to grow, until he confessed the truth: at that point, the fairy called birds that came to peck his nose, until he returned to normal. 
Nose stealer: For this game it needed a poster, previously created by the teacher, with two Pinocchio representations on (one for a team and one for the other), with the nose composed of many boxes in order to stick on and detach cards from it, which simulated Pinocchio's nose getting bigger or shorter. At the beginning of the game, three cards for each team were stuck on the board. The game involved two phases that followed one another many times: a first phase in which the flag-stealing was played, and a second phase in which a question relating to the story just read was answered. The two teams were arranged in two rows, and each player was assigned a progressive number, from one forward. $1 \mathrm{M}$, supported by the section teacher, placed himself between the two teams and called a number by holding the handkerchief. The player of each team who had that number ran to take the handkerchief and went back to take it to his team. The teacher read out the question to the winning player and proposed the two answers. The player had to guess the right one: in case of positive answer, then the nose of his Pinocchio got shorter by losing one box, otherwise it increased by one. The team that first minimized Pinocchio's nose won, and the team with the nose reaching the bottom of the poster lost.

\section{Week 5}

Week 5 was dedicated to the part of the fairy tale of Pinocchio in which the protagonist got to the Land of Toys.

Pinocchio would often hear a voice, that is, his conscience: it was the talking cricket that persisted in giving advice to the protagonist, but which was not listened to.

The talking cricket: For this first activity it needed a lot of sheets with a puppet drawn on them, and a sheet with a talking cricket on it. In addition, a circle was placed on the ground that served as a cage, in which a player had to enter. The children formed three teams and were placed on the starting line, far from both the circle and the sheets; these sheets were placed face down. At the start, all the players ran to get a sheet: the player with the talking cricket had to run away in the cage, while the others ran after him. Obviously, no one had to reveal to the others what was drawn on their sheet, so that they could capture the talking cricket if he had taken a puppet, or he would have run away into the cage if he had taken the talking cricket. Points were awarded as follows: if the cricket managed to enter the cage without being touched, then his team would have been assigned a point, otherwise no points would have been assigned. In this way each team had to try to catch the opposing teammates and not their own ones, otherwise they risked taking their own cricket and therefore not score any points. After scoring a point, the sheets were placed back on the ground and the game started back.

Afterwards, the children were offered the opportunity to reproduce the Land of Toys, where Pinocchio spent his days by playing with his friends. The game and the fun in the Land of Toys were characterized by colours, music and movement.

The Land of Toys is celebrating: The teacher was placed in the centre of the gym, playing a piano, and was accompanied by $1 \mathrm{M}$, which was playing a tambourine. The children, entering into a circle and holding it with their hands, had to move throughout the space, following the rhythm played by the teacher and $1 \mathrm{M}$ : if the teacher played a slow music, the children had to move slowly in the surrounding space; if the rhythm of the music was faster, instead, the children had to run. The main purpose of this activity was to encourage the harmonious development of personality and develop their cognitive and relational skills; moreover, we wanted to let them learn to perceive, listen to, search for and discriminate sounds within meaningful learning contexts. By interacting with the soundscape, children could fully live their own corporeity, experiencing pleasure in movement. 
Celebration in the Land of Toys was going on...

The magic tarp: The children were arranged in a circle around the game parachute, in the middle of which there was a gap, and each took a handle; at the start of the teacher, they had to shake the parachute quickly. At a certain point the teacher placed a ball in the middle of the tarp and the children had to try to make it fall into the central hole, by moving the parachute. Then the teacher put coloured sponges in the middle of the tarp and the children had to try to make them jump out of the parachute as soon as possible. Finally, each child was assigned a colour, depending on his position in front of the tarp; the teacher gave commands, such as "blue colours exchanging" or "red colours exchanging" and the children corresponding to the colour mentioned switched places, passing under the tarp.

We believe that the body action makes experience pleasant emotions and sensations of relaxation and tension, but also the satisfaction of the control of gestures, in the coordination with others. For these reasons, we decided to encourage the participation of $1 \mathrm{M}$ just like his companions.

\section{Week 6}

The teacher concluded the reading of the fairy tale The Adventures of Pinocchio, focusing particularly on the moment in which the protagonist was swallowed by the whale, and turned into a real child. The teacher proposed to reproduce the environment in which Pinocchio got lost, i.e. the belly of the whale.

The bandaged children train: The children were arranged in a single line, while the teacher distributed a bandage to each student, with which they had to cover their eyes. Afterwards, the teacher explained the children that they had to place their hands on the shoulders of the mate standing in front of them, without ever lifting them up; when all the children were bandaged, the teacher called the name of the first child in the row. This child went in the direction from which he heard the sound of the teacher's voice coming, and all the children behind him had to follow him. The teacher moved in space and the leader had to pay attention to recognize, each time, where he heard his name coming from, and had to go in that direction: the classmates had to be careful not to move away from the line (being blindfolded they could bang into something). After having called a couple of times the name of the first member of the row, it was the turn of the second one. The goal of this game was to develop orientation in space and attention to recognize the point from which a sound came. In addition, 1M had the opportunity to actively participate in the game.

\section{But beware: someone might have woken up...}

The whale: The teacher placed two rows of chairs in parallel, with the backs turned inwards, and placed a plastic rod on top of each pair of chairs. The rods had to be placed once on the two backs, once on the two seats, and so on in an alternating way. The game consisted in carrying out the path, passing on and under the rod without making it fall; otherwise the whale would have woken up and eaten all the children. There was also a difficulty: the children were able to move in the path only once they would have heard $1 \mathrm{M}$ playing a tambourine (following the teacher's commands) and had to freeze when it would have stopped. The sounds played with the tambourine, in fact, would imitate the snoring of the whale.

So many sensations! As a last game inspired by the fairy tale of Pinocchio, the teacher organized a sensory path, referring to the moment when the protagonist turned into a real child and experienced the real world through the touch. The teacher asked the children to form a single line and remain barefoot; then he distributed a band to each child to place on their eyes, and prepared the material that then placed in the sensory bowls: the latter were plastic, medium-sized and high-edged containers, placed one after the other. 
The teacher called one child at a time and accompanied him throughout the path: at first the student immersed his feet in a bowl containing sand; when entering the next bowl he rested his feet on pebbles; in the third bowl he came into contact with leaves; immediately afterwards he experienced the sensation resulting from touching the cotton wool, and finally he immersed his feet in a bowl full of water. Then the teacher removed the containers, tool away the bandage from the children's eyes, and asked them to guess which materials they had come into contact with and what sensations these arose in them.

Sensory games are an important opportunity for children to explore, experience and discover the world around them. They also arouse curiosity and a desire for discovery. Since the proposed activity was focused on the development of tactile perception, $1 \mathrm{M}$ was able to participate in the same way as his mates too.

\section{Week 7}

The lesson began with the reading of the fairy tale of Snow White and the seven dwarfs in the classroom of the section involved.

As already mentioned, this week $1 \mathrm{M}$ was absent.

The part of the story that was taken into consideration is that relating to the beginning of the fairy tale until Snow White got lost in the woods.

Mirror, mirror on the wall: The first activity was inspired by the scene of the bad witch of Snow White, standing in front of the mirror, and consisted in dividing the children in pairs and placing them in front of each other. One member of the couple acted as a mirror, the other played the role of the witch; at the start of the teacher, the witches made a movement (as they wish) and the mirrors had to reproduce it faithfully. After a few minutes the teacher reversed the roles. Through this game, the child recognized the signals and rhythms of others' body and felt satisfaction in controlling gestures and coordinating with others.

While walking in the woods, Snow White was attracted by the chirping birds, the squeaking squirrels and the flying butterflies.

The boxes: In this regard, the children were invited to reproduce the animals of the forest through the game of boxes that, for good weather conditions, was played in the garden of the school: when the teacher said "boxes closed" all the children crouched down on the ground, while when he exclaimed the name of an animal, the boxes opened and the animal called by the teacher came out. The game continued by imitating various animals of the woods. The activity aimed at expressing oneself through dramatization, by exploring the potentialities offered by one's own body.

It was so pleasant to be in the woods for Snow White, to the extent that she kept playing with the animals.

Searching for Snow White: The teacher chose a child who took on the role of Snow White, while all the others represented the animals of the woods. Snow White had the task of hiding herself, but the animals started to count. When the count was over, everyone went and searched for her; when a child found her, he hid with her, so did all the other children. The game was considered over when only one child was left out. The game was repeatable depending on the time available. The aim was to promote the ability to orient oneself in space, move and communicate according to imagination and fantasy. 


\section{Week 8}

The lesson began with the reading of the fairy tale of Snow White in the classroom of the section involved. In particular, it dealt with the moment of the story in which the protagonist, after wandering for a while in the woods, found herself in front of a small house where the seven dwarfs lived, who were then working in a nearby mine. For this reason, the motor activities proposed for this week recalled both part of the work the dwarfs did in the mine, and the time when they went back home.

Dwarfs for a moment: The first activity began with listening to the song of the seven dwarfs, which went like this:

There on the mountain ring ring ring the seven dwarfs wake up (2 times) / there on the mountain yum yum yum the seven dwarfs eat (2 times) / there on the mountain gobble gobble gobble the seven dwarfs drink (2 times) / there on the mountain poom poom the seven dwarfs work (2 times) / there on the mountain tra-la-la the seven dwarfs dance (2 times) / there on the mountain ssssssssst the seven dwarfs sleep (2 times).

The students had to imitate the dwarfs by reproducing the actions highlighted in the text, to the rhythm of music. The teacher suggested new sequences to play, for example, "crawling", "jumping", "playing the flute", etc. Through this experience, the children explored their own sound-expression and symbolic-representative skills, and the listening to the sound productions opened them up to the pleasure of making music and to the sense of sharing. For this reason, $1 \mathrm{M}$ could take part in the exercise.

How hard the work in the mine is for the seven dwarfs! Let's run and help them!

The wheelbarrow: The activity proposed was that of the wheelbarrow, developed to imitate the work of the seven dwarfs into the mine. The children were divided into three teams, consisting of six components each, and had to move from one end of the gym to the other. A child grasped the legs of one of his mates by pushing him forward, while the latter moved by walking on his hands. Each pair had to carry a foam ball on the other side of the gym, placed between the legs of the child who was acting as a wheelbarrow. The objects carried symbolized the diamonds found by the dwarfs. After the first round, the children exchanged roles and continued the relay; the team that managed to carry the most balls got the win.

The exercise aimed at developing the ability to play constructively with others, controlling the performance of the gesture and assessing the risks. $1 \mathrm{M}$ had the opportunity to perform the exercise, playing the role of the wheelbarrow for he was guided by a mate.

Once all the diamonds were found, it was time for the dwarfs to go back home, but the path was not so simple.

The path of the dwarfs: The teacher invited the children to take off their shoes, while he built a path on the ground with curves, broken lines and various irregularities, by using the cellophane with bubbles; the task of the student was to carry out the entire path by imitating the gait of the dwarfs, i.e. by taking small and short steps, without leaving the path. This specific material was chosen to allow $1 \mathrm{M}$ performing the path just like his mates. The main objective of the activity was to be able to mimic the pace of the seven dwarfs, being careful to respect the marked path, and by staying within the limits.

\section{Week 9}

During this meeting, the teacher continued reading the fairy tale of Snow White, focusing on the moment in which the protagonist got poisoned, and on the subsequent meeting with the Prince Charming. 
The poisoned apple: The children were divided into two teams, each of which positioned itself in its own half of the field and was introduced with the game of the poisoned apple, recalling the plot of the fairy tale. After choosing the team that had to start first, the child who held ball possession had to throw it and try to hit the opponents in the other half of the field. If the ball, before hitting the opponent, touched the ground or was avoided, the catch was not considered valid; on the contrary, if the player got hit directly, he had to run in the area of the prisoners at the bottom of the opponents' field. There he had to wait for someone of his teammates to intercept and stop a shot on the fly and releasing him/her from his imprisonment. The game was won by who succeeded in hitting all the opponents.

The relay of the apples: By resuming the previous division into teams, the children had to perform the relay of the apples, which consisted in slalom around the marker cones, with jumps in the circles first with feet held together and then performed by standing on one foot, walking balanced on a low beam and jumping over two obstacles. At the end of the path they found a ball, which, also in this case, symbolized an apple; at that point, they had to throw the ball in a basket. The team that succeeded in scoring the highest number of baskets got the win. These two games aimed at respecting the rules and accepting defeat, while having fun with others in a constructive and positive way.

With the kiss of her true love, Snow White woke up! A little bird, a little dog, a kitten, an owl, a frog and a snake were watching over the protagonist. They ran to spread the good news to all the other animals in the woods.

The call of the animals: In this regard, the teacher attributed to each child an animal mentioned above, without being heard by others. Afterwards, the children were blindfolded and each one had to reproduce the cry of the animal that was assigned to him/her, trying to reach the mates that reproduced his own sound by using only the hearing. The purpose of this sound experience was to codify the perceived sounds and discriminate their provenience, by refining the hearing. Thanks to this game modality, $1 \mathrm{M}$ was actively involved and was able to experience his potentialities just like his teammates.

\section{Week 10}

The final week of the "Fiabe in movimento" (Moving Fairy Tales) project was dedicated to the final debriefing, in which students took a ball of wool and placed themselves in circle. The teacher was the first to say: "What do I take with me from this experience? I take away the joy". Then he held a thread end for whoever he wanted, and the latter, in turn, had to answer the question. The second one also held a thread end and threw the ball, and then a web was formed. Everyone, at the end, had a piece of wire useful to remember the experience.

Afterwards, the teacher asked his students to mention which games they had preferred and gave them the chance to repeat them.

\section{CRITERIA FOR THE EVALUATION OF THE EXPERIMENTAL PEDAGOGICAL ACTIVITY}

Below the scheme that frames the criteria with which the experimental pedagogical activity was evaluated; it is clear that this table takes into account, at the same time, both the motor-sports aspects and the didacticpedagogical and social ones (Di Palma, Rosa \& Ascione, 2019; Ericsson, \& Karlsson, 2014; Whipp et al, 2011). 


\begin{tabular}{|c|c|c|c|c|}
\hline \multirow[t]{2}{*}{ INDICATORS } & \multicolumn{4}{|c|}{ DESCRIPTORS / LEVELS } \\
\hline & INITIAL & BASE & INTERMEDIATE & ADVANCED \\
\hline $\begin{array}{l}\text { Walking } \\
\text { running }\end{array}$ & $\begin{array}{l}\text { He/she can walk } \\
\text { forwards and } \\
\text { backwards, does not } \\
\text { distinguish between } \\
\text { directions, is not } \\
\text { aware of the } \\
\text { functionality of the } \\
\text { arms when running } \\
\text { and moving. He/she } \\
\text { moves in a confusing } \\
\text { way, without following } \\
\text { the rhythm of music. } \\
\text { He/she is unaware of } \\
\text { the risk of } \\
\text { movements. }\end{array}$ & $\begin{array}{l}\text { He/she knows how to } \\
\text { walk and run forwards } \\
\text { and backwards, has } \\
\text { difficulty } \\
\text { distinguishing } \\
\text { directions, uses his } \\
\text { arms in an } \\
\text { uncoordinated way. } \\
\text { He/she only follows } \\
\text { music in some cases, } \\
\text { is unaware of the risk } \\
\text { of movements, but } \\
\text { has the perception of } \\
\text { the space in which } \\
\text { he/she is. }\end{array}$ & $\begin{array}{l}\text { He/she can follow all } \\
\text { directions (forward, } \\
\text { backwards, left, right) } \\
\text { using his arms in an } \\
\text { advantageous } \\
\text { situation. He/she } \\
\text { can't assess the risk } \\
\text { of movements and is } \\
\text { aware of the space } \\
\text { around him/her. }\end{array}$ & $\begin{array}{l}\text { He/she can follow all } \\
\text { directions (forward, } \\
\text { backward, left, right } \\
\text { and diagonally) using } \\
\text { his arms in an } \\
\text { advantageous } \\
\text { situation. He/she also } \\
\text { moves to the rhythm } \\
\text { of music, can assess } \\
\text { the risk of movement } \\
\text { and has a very good } \\
\text { perception of space. }\end{array}$ \\
\hline Throwing & $\begin{array}{l}\text { He/she can feel the } \\
\text { distance but has little } \\
\text { control over the ball. } \\
\text { The momentum of his } \\
\text { limbs is not sufficient } \\
\text { to calibrate the thrust; } \\
\text { his body posture does } \\
\text { not allow performing } \\
\text { the throw in a } \\
\text { coordinated way; } \\
\text { moreover he/she is } \\
\text { not able to predict the } \\
\text { trajectories. }\end{array}$ & $\begin{array}{l}\text { He/she can feel the } \\
\text { distance and has } \\
\text { sufficient control over } \\
\text { the ball. The } \\
\text { momentum of his } \\
\text { limbs is not sufficient } \\
\text { to calibrate the thrust, } \\
\text { his body posture is in } \\
\text { balance, but finds it } \\
\text { difficult to throw } \\
\text { something in a } \\
\text { coordinated way. } \\
\text { He/she does not } \\
\text { always assess } \\
\text { trajectories } \\
\text { accurately. }\end{array}$ & $\begin{array}{l}\text { He/she can perceive } \\
\text { the distance of the } \\
\text { throw and has good } \\
\text { control over the ball. } \\
\text { The balance of the } \\
\text { lower limbs is not } \\
\text { controlled, and } \\
\text { therefore the thrust is } \\
\text { not fully calibrated. } \\
\text { He/she can evaluate } \\
\text { the trajectories and } \\
\text { can keep the body in } \\
\text { balance. }\end{array}$ & $\begin{array}{l}\text { He/she has good } \\
\text { balance and aim and } \\
\text { is able to accurately } \\
\text { assess distances and } \\
\text { trajectories. He/she } \\
\text { has good } \\
\text { coordination that } \\
\text { grants him/her full } \\
\text { control over the ball. } \\
\text { The momentum of the } \\
\text { lower limbs allows } \\
\text { him/her well } \\
\text { calibrating the thrust } \\
\text { while keeping his } \\
\text { body balanced. }\end{array}$ \\
\hline $\begin{array}{l}\text { Crawling anc } \\
\text { rolling }\end{array}$ & $\begin{array}{l}\text { He/she is not able to } \\
\text { crawl on different } \\
\text { surfaces, following } \\
\text { the lines marked on } \\
\text { the ground. He/she } \\
\text { can crawl on the } \\
\text { ground in prone } \\
\text { position, standing on } \\
\text { his back and on his } \\
\text { side. He/she can't } \\
\text { crawl below an } \\
\text { obstacle or roll left or } \\
\text { right. }\end{array}$ & $\begin{array}{l}\text { He/she can crawl in } \\
\text { any way on different } \\
\text { surfaces, partly } \\
\text { following the lines } \\
\text { marked on the } \\
\text { ground. He/she can } \\
\text { crawl on the ground in } \\
\text { prone position, lying } \\
\text { on his back and on his } \\
\text { side. He/she can't } \\
\text { crawl under an } \\
\text { obstacle and has } \\
\text { difficulty in rolling both } \\
\text { left and right. }\end{array}$ & $\begin{array}{l}\text { He/she can crawl in } \\
\text { every way on different } \\
\text { surfaces, following } \\
\text { the lines marked on } \\
\text { the ground. He/she } \\
\text { can crawl on the } \\
\text { ground in prone } \\
\text { position, lying on his } \\
\text { back and on his side. } \\
\text { He/she can crawl } \\
\text { under an obstacle } \\
\text { and can roll both right } \\
\text { and left. }\end{array}$ & $\begin{array}{l}\text { He/she can easily } \\
\text { crawl on different } \\
\text { surfaces, following } \\
\text { the lines marked on } \\
\text { the ground. He/she } \\
\text { can crawl on the } \\
\text { ground in prone } \\
\text { position, lying on his } \\
\text { back and on his side. } \\
\text { He/she can crawl } \\
\text { under a sequence of } \\
\text { obstacles and can } \\
\text { easily roll left and } \\
\text { right. }\end{array}$ \\
\hline Jumping & $\begin{array}{l}\text { He/she can only jump } \\
\text { by holding feet } \\
\text { together, in an } \\
\text { uncoordinated way, }\end{array}$ & $\begin{array}{l}\text { He/she can jump with } \\
\text { feet together and only } \\
\text { forward in an } \\
\text { uncoordinated way. }\end{array}$ & $\begin{array}{l}\text { He/she can jump } \\
\text { forward, backward, } \\
\text { into/outside of a } \\
\text { perimeter with feet }\end{array}$ & $\begin{array}{l}\text { He/she can jump } \\
\text { forward, backward, } \\
\text { into/outside of a } \\
\text { perimeter with feet }\end{array}$ \\
\hline
\end{tabular}




\begin{tabular}{|c|c|c|c|c|}
\hline & $\begin{array}{l}\text { losing balance many } \\
\text { times over. He/she } \\
\text { can't calibrate the } \\
\text { thrust needed to raise } \\
\text { from the ground. }\end{array}$ & $\begin{array}{l}\text { He/she often loses } \\
\text { balance and does not } \\
\text { calibrate the } \\
\text { necessary thrust. }\end{array}$ & $\begin{array}{l}\text { together, in a } \\
\text { coordinated way but } \\
\text { showing instability in } \\
\text { some cases. He/she } \\
\text { can calibrate the } \\
\text { necessary thrust. }\end{array}$ & $\begin{array}{l}\text { together, with } \\
\text { confidence and } \\
\text { balance; he/she can } \\
\text { jump over obstacles } \\
\text { of different heights, } \\
\text { calibrating the } \\
\text { necessary thrust. }\end{array}$ \\
\hline Parti & $\begin{array}{l}\text { He/she needs to be } \\
\text { continuously } \\
\text { stimulated to } \\
\text { complete the } \\
\text { proposed activity. }\end{array}$ & $\begin{array}{l}\text { He/she hardly } \\
\text { focuses on a } \\
\text { particular activity and } \\
\text { needs to be } \\
\text { stimulated and } \\
\text { involved. }\end{array}$ & $\begin{array}{l}\text { He/she takes part } \\
\text { with enthusiasm in } \\
\text { the proposed } \\
\text { activities rand } \\
\text { completes them } \\
\text { independently. }\end{array}$ & $\begin{array}{l}\text { He/she participates } \\
\text { with commitment, } \\
\text { curiosity, and interest } \\
\text { in the proposed } \\
\text { activities by } \\
\text { completing them with } \\
\text { accuracy and } \\
\text { autonomy. }\end{array}$ \\
\hline Relationship & $\begin{array}{l}\text { He/she prefers } \\
\text { solitary game. His } \\
\text { relationship with } \\
\text { adults is essential, } \\
\text { based on the needs } \\
\text { for affective restraint } \\
\text { that implements by } \\
\text { attracting attention } \\
\text { with behaviours. }\end{array}$ & $\begin{array}{l}\text { The relationship with } \\
\text { his mates is limited to } \\
\text { the small group. } \\
\text { He/she only relates } \\
\text { with adults to } \\
\text { requests for help. }\end{array}$ & $\begin{array}{l}\text { He/she establishes } \\
\text { game relationships } \\
\text { with his mates, } \\
\text { demonstrating } \\
\text { acceptance of the } \\
\text { rules. He/she relates } \\
\text { with adults in an } \\
\text { appropriate way for } \\
\text { communicating a } \\
\text { requesting for help. }\end{array}$ & $\begin{array}{l}\text { He/she establishes } \\
\text { collaborative } \\
\text { relationships with his } \\
\text { mates in all activities, } \\
\text { showing considerable } \\
\text { respect for the rules. } \\
\text { He/she deals with } \\
\text { adults in an } \\
\text { appropriate way, } \\
\text { respecting the } \\
\text { different situations. }\end{array}$ \\
\hline $\begin{array}{l}\text { Autonomy in } \\
\text { the use of } \\
\text { materials }\end{array}$ & $\begin{array}{l}\text { Faced with an } \\
\text { unfamiliar object, } \\
\text { he/she cannot } \\
\text { understand its use, } \\
\text { and needs a practical } \\
\text { demonstration. } \\
\text { He/she uses the } \\
\text { material in a non- } \\
\text { autonomous way, } \\
\text { asking for continuous } \\
\text { help from the teacher } \\
\text { and mate }\end{array}$ & $\begin{array}{l}\text { He/she uses the } \\
\text { materials in a semi- } \\
\text { autonomous way; } \\
\text { when faced with an } \\
\text { unfamiliar object, } \\
\text { he/she asks for help } \\
\text { and confirmation from } \\
\text { adults and peers. }\end{array}$ & $\begin{array}{l}\text { He/she uses the } \\
\text { materials } \\
\text { autonomously, when } \\
\text { faced with an } \\
\text { unfamiliar object } \\
\text { he/she tries to use it } \\
\text { alone by making } \\
\text { attempts. }\end{array}$ & $\begin{array}{l}\text { He/she uses the } \\
\text { materials in a totally } \\
\text { autonomous way, } \\
\text { compares } \\
\text { himself/herself with } \\
\text { his peers by helping } \\
\text { them; he/she is aware } \\
\text { of the use of new } \\
\text { materials. }\end{array}$ \\
\hline
\end{tabular}

\section{EVALUATION OUTCOMES}

The evaluation was proposed both ex ante, in order to identify the starting level for each parameter to be evaluated for each individual student, and ex post, so as to be able to appreciate the effect that the experimental activity was able to bring. Since they were children still attending kindergarten, it was considered appropriate not to express a numerical "mark ", but rather a gradual judgment with this scale: "initial - basic intermediate - advanced". 
Assumed ex ante evaluation:

\begin{tabular}{|c|c|c|c|c|c|c|c|}
\hline & $\begin{array}{l}\text { Walking and } \\
\text { running }\end{array}$ & Throwing & $\begin{array}{l}\text { Crawling } \\
\text { and rolling }\end{array}$ & Jumping & Participation & Relationship & $\begin{array}{l}\text { Autonomy in } \\
\text { the use of } \\
\text { materials }\end{array}$ \\
\hline $\begin{array}{l}1 \\
M\end{array}$ & Basic & Initial & Basic & Initial & Initial & Initial & Initial \\
\hline $\begin{array}{l}2 \\
F\end{array}$ & Advanced & Intermediate & Basic & Basic & Intermediate & Basic & Basic \\
\hline $\begin{array}{l}3 \\
F\end{array}$ & Intermediate & Basic & Intermediate & Basic & Intermediate & Intermediate & Basic \\
\hline $\begin{array}{l}4 \\
M\end{array}$ & Advanced & Intermediate & Intermediate & Intermediate & Advanced & Intermediate & Intermediate \\
\hline $\begin{array}{l}5 \\
F\end{array}$ & Intermediate & Basic & Basic & Initial & Basic & Intermediate & Basic \\
\hline $\begin{array}{l}6 \\
M\end{array}$ & Intermediate & Basic & Intermediate & Intermediate & Basic & Basic & Initial \\
\hline $\begin{array}{l}7 \\
M\end{array}$ & Basic & Intermediate & Initial & Basic & Intermediate & Basic & Initial \\
\hline $\begin{array}{l}8 \\
M\end{array}$ & Intermediate & Intermediate & Basic & Intermediate & Intermediate & Intermediate & Intermediate \\
\hline $\begin{array}{l}9 \\
F\end{array}$ & Intermediate & Basic & Intermediate & Basic & Intermediate & Intermediate & Basic \\
\hline $\begin{array}{l}10 \\
M\end{array}$ & Basic & Basic & Initial & Basic & Intermediate & Basic & Intermediate \\
\hline $\begin{array}{l}11 \\
F\end{array}$ & Advanced & Intermediate & Intermediate & Basic & Advanced & Intermediate & Intermediate \\
\hline $\begin{array}{l}12 \\
F\end{array}$ & Intermediate & Initial & Basic & Initial & Intermediate & Intermediate & Basic \\
\hline $\begin{array}{l}13 \\
M\end{array}$ & Intermediate & Basic & Basic & Intermediate & Basic & Basic & Initial \\
\hline $\begin{array}{l}14 \\
F\end{array}$ & Basic & Basic & Basic & Intermediate & Intermediate & Intermediate & Intermediate \\
\hline $\begin{array}{l}15 \\
F\end{array}$ & Intermediate & Intermediate & Initial & Basic & Basic & Intermediate & Intermediate \\
\hline $\begin{array}{l}16 \\
F\end{array}$ & Intermediate & Initial & Intermediate & Basic & Advanced & Intermediate & Basic \\
\hline $\begin{array}{l}17 \\
M\end{array}$ & Intermediate & Intermediate & Basic & Intermediate & Intermediate & Basic & Basic \\
\hline $\begin{array}{l}18 \\
F\end{array}$ & Intermediate & Basic & Intermediate & Basic & Intermediate & Basic & Intermediate \\
\hline
\end{tabular}


Assumed ex post evaluation:

\begin{tabular}{|c|c|c|c|c|c|c|c|}
\hline & $\begin{array}{l}\text { Walking } \\
\text { and } \\
\text { running }\end{array}$ & Throwing & $\begin{array}{l}\text { Crawling } \\
\text { and rolling }\end{array}$ & Jumping & Participation & Relationship & $\begin{array}{l}\text { Autonomy in } \\
\text { the use of } \\
\text { materials }\end{array}$ \\
\hline $\begin{array}{l}1 \\
M\end{array}$ & Basic & Intermediate & Intermediate & Basic & Intermediate & Basic & Basic \\
\hline $\begin{array}{l}2 \\
F\end{array}$ & Advanced & Intermediate & Intermediate & Intermediate & Advanced & Intermediate & Intermediate \\
\hline $\begin{array}{l}3 \\
F\end{array}$ & Advanced & Intermediate & Intermediate & Basic & Advanced & Advanced & Intermediate \\
\hline $\begin{array}{l}4 \\
M\end{array}$ & Advanced & Advanced & Intermediate & Advanced & Advanced & Intermediate & Intermediate \\
\hline $\begin{array}{l}5 \\
F\end{array}$ & Advanced & Intermediate & Basic & Basic & Intermediate & Advanced & Basic \\
\hline $\begin{array}{l}6 \\
M\end{array}$ & Intermediate & Intermediate & Advanced & Advanced & Intermediate & Intermediate & Basic \\
\hline $\begin{array}{l}7 \\
M\end{array}$ & Intermediate & Advanced & Basic & Intermediate & Intermediate & Intermediate & Basic \\
\hline $\begin{array}{l}8 \\
M\end{array}$ & Advanced & Intermediate & Intermediate & Advanced & Intermediate & Advanced & Advanced \\
\hline $\begin{array}{l}9 \\
F\end{array}$ & Advanced & Intermediate & Advanced & Base & Advanced & Intermediate & Intermediate \\
\hline $\begin{array}{l}10 \\
M\end{array}$ & Intermediate & Intermediate & Basic & Intermediate & Intermediate & Intermediate & Advanced \\
\hline $\begin{array}{l}11 \\
F\end{array}$ & Advanced & Intermediate & Advanced & Intermediate & Advanced & Advanced & Intermediate \\
\hline $\begin{array}{l}12 \\
F\end{array}$ & Advanced & Basic & Basic & Basic & Advanced & Advanced & Intermediate \\
\hline $\begin{array}{l}13 \\
M\end{array}$ & Advanced & Intermediate & Basic & Intermediate & Intermediate & Intermediate & Basic \\
\hline $\begin{array}{l}14 \\
F\end{array}$ & Intermediate & Intermediate & Intermediate & Intermediate & Intermediate & Advanced & Intermediate \\
\hline $\begin{array}{l}15 \\
F\end{array}$ & Advanced & Advanced & Basic & Intermediate & Intermediate & Advanced & Intermediate \\
\hline $\begin{array}{l}16 \\
F\end{array}$ & Advanced & Basic & Advanced & Intermediate & Advanced & Intermediate & Basic \\
\hline $\begin{array}{l}17 \\
M\end{array}$ & Advanced & Intermediate & Intermediate & Advanced & Intermediate & Intermediate & Basic \\
\hline $\begin{array}{l}18 \\
F\end{array}$ & Intermediate & Intermediate & Intermediate & Intermediate & Advanced & Intermediate & Advanced \\
\hline
\end{tabular}

\section{DISCUSSION AND CONCLUSION}

The activities of the "Fiabe in movimento" (Moving Fairy Tales) project were proposed mainly in a playful way, through structured games designed to increase children's motor skills and abilities; through this project the aim was to develop not only the motor-sports aspect, but also the pedagogical-educational one. In fact, we believe that the telling of a fairy tale satisfies the natural desire that children have to feel the narration of events, which develops in the age group we took into account, and which evolves further with independent reading. Very often, children identify themselves with the characters of the stories and enthusiastically accept 
the ideas and strategies that the fairy tales propose to their problems; in fact, they induce students to rework the problematic situation in a playful way, and to work actively on their own behaviour. The events that are narrated through the fairy tale have a deep educational value, and allow getting to know some components of our inner world; moreover, fairy tales have the potential to bring together different realities, involving also children with specific needs and requirements in the same way, such as $1 \mathrm{M}$. The activities pursued the aim of promoting, at the same time, the rational-fantastic thought and motor skills. In particular, direct experience, game, conscious experimentation of one's own body, working by making attempts allowed some children showing considerable improvement and achieving the objectives set. The criticalities found in the project were mainly related to $1 \mathrm{M}$ because, in some cases, he showed closeness towards motor activities and revealed difficulties in distinguishing the conversations and their right order, if there was noise in the environment. However, everything got managed: it was possible to reduce the natural isolation of $1 \mathrm{M}$ and promote his inclusion. Nevertheless, there were some criticalities showed by other students too, linked to the time available and the need for greater support; in fact, it should be noted that, for this reason, some children remained at the same starting level. The experimentation carried out lays the foundations for future empirical studies on the game-sport pair as a school tool for the growth of motor, sports, pedagogical and sociorelational skills, which represent the basis for the training of the individual.

\section{AUTHORS' CONTRIBUTIONS}

The manuscript is the result of a collective work of the authors, the specific contribution of which is to be referred to as follows: the Introduction is to be attributed to Giuseppe Madonna, Paragraphs: "Experimental School Experience Activities Program" - "Discussion and conclusion" are to be attributed to Antonio Ascione, Paragraphs: "The Structure of the Pedagogical Experimental Project" - "Criteria for the evaluation of the experimental pedagogical activity" - "Evaluation Outcomes" are to be attributed to Davide Di Palma.

\section{REFERENCES}

Ascione, A., Di Palma, D., \& Napolitano, S. Social Inclusion and Education Through Sport and Technology. Sport Science 11 (2018) 1: 52-56.

Ascione, A., Di Palma, D., \& Rosa, R. (2019). Innovative educational methodologies and corporeity factor. Journal of Human Sport and Exercise, 14(2proc), S159-S168. https://doi.org/10.14198/ihse.2019.14.proc2.02

Bailey, R. (2005). Evaluating the relationship between physical education, sport and social inclusion. Educational review, 57(1), 71-90. https://doi.org/10.1080/0013191042000274196

Di Palma, D., Ascione, A., \& Napolitano, S. (2018). Education to school inclusion through sport. Sport Science 11 (2018) Suppl 1: 42-46.

Di Palma, D., Rosa, R., \& Ascione, A. (2019). Experimental pedagogy: New technologies. Journal of Human Sport and Exercise, 14(2proc), S149-S158. https://doi.org/10.14198//hse.2019.14.proc2.01

Ericsson, I., \& Karlsson, M. K. (2014). Motor skills and school performance in children with daily physical education in school-a 9-year intervention study. Scandinavian journal of medicine \& science in sports, 24(2), 273-278. https://doi.org/10.1111/j.1600-0838.2012.01458.x

Männistö, J. P., Cantell, M., Huovinen, T., Kooistra, L., \& Larkin, D. (2006). A school-based movement programme for children with motor learning difficulty. European Physical Education Review, 12(3), 273-287. https://doi.org/10.1177/1356336x06069274

McKenzie, T. L., Sallis, J. F., Prochaska, J. J., Conway, T. L., Marshall, S. J., \& Rosengard, P. (2010). Evaluation of a two-year middle-school physical education intervention: M-SPAN. People, 25(8), 26. https://doi.org/10.1249/01.mss.0000135792.20358.4d 
Napolitano, S., Ascione, A., \& Di Palma, D. (2018). Analysis of posture and its impact on performance in women's water polo. Sport Science 11 (2018) Suppl 1: 85-91.

Rosa, R., Ascione, A., \& Di Palma, D. (2019). Biodanza laboratory and experimental pedagogy. Journal of Human Sport and Exercise, 14(2proc), S169-S177. https://doi.org/10.14198/ihse.2019.14.proc2.03

Whipp, P. R., Hutton, H., Grove, J. R., \& Jackson, B. (2011). Outsourcing physical education in primary schools: Evaluating the impact of externally provided programmes on generalist teachers. AsiaPacific Journal of Health, Sport and Physical Education, 2(2), 67-77. https://doi.org/10.1080/18377122.2011.9730352

\section{(c)}

This work is licensed under a Attribution-NonCommercial-NoDerivatives 4.0 International (CC BY-NC-ND 4.0). 